\title{
Increasing The Value-Added of Production Citronella Oil and Carrageenan in Rungkut Barata Surabaya
}

\author{
Author \\ Dwi Yuli Pujiastuti (Orcid ID. 0000-0001-8630-6921), \\ Laksmi Sulmartiwi (Orcid ID. 0000-0002-5000-0151), \\ Ahmad Shofy Mubarak (Orcid ID. 0000-0002-0828-3194) \\ Correspondence \\ Department of Marine, Faculty of Fisheries and Marine, Universitas Airlangga, Surabaya 60115 \\ dwiyp@fpk.unair.ac.id
}

\begin{abstract}
In this PKM program,our partner is residents in Rungkut Barata,Surabaya, East Java Province. This community has generated the production of citronella oil. However, the product only in the form of citronella oil in a simple package. Citronella oil from the refining process is one of the jobs for the people in Rungkut Barata, where to improve welfare, a product diversification process is necessary. Seaweed is forms of algae that grow in the sea and has a biological activity for health. Carrageenan is the product result of seaweed extraction with several functions as thickener, emulsifier, suspension, and stabilizer. The pharmaceutical industry uses carrageenan to manufacture drugs, syrups, tablets, toothpaste, and shampoo. The cosmetics industry uses it as a gelling agent or binding agent.

Based on interviews and observations in the field, there are two main focuses of the problems currently faced by partners, namely: 1) lack of knowledge about non-consumption seaweed and 2) product diversification of seaweed and citronella oil which has an added value.Some of the things planned by the PKM team are innovating citronella oil to be aromatic soap and providing training and mentoring for financial analysis, soap packaging and marketing. This activity aims to transfer knowledge of making soap, develop the partner's creativity, increase soap production, and improve the welfare of the partner.

This activity was realized with an approach to make a sustainable cooperation program until theend of PKM creating a family atmosphere between the two and understanding that the problems experienced were a shared problem so that they could be solved together according to the level of responsibility to achieve the expected benefits, namely increased yields, production and productivity and competitiveness, independence and welfare of the community.
\end{abstract}

Keywords : Aromatic Soap, Carrageenan, Citronella Oil, Creativity, Welfare.

Received: 20 November 2020. Accepted: 23 June 2021

\section{Introduction}

Indonesia is a country rich in living natural resources, so it is called an agricultural country. Indonesia produces 4050 types of essential oil-producing plants from 80 kinds of essential oils traded in the world, and only a few of these types of essential oils have entered the world market, including patchouli, citronella, gaharu, cloves, jasmine, cananga, eucalyptus, sandalwood and vetiver (Faidliyah, 2017). Aromatherapy is an alternative treatment method derived from volatile plant materials, first known in essential oils. Essential oils have volatile components in some plants with specific characteristics. Currently, essential oils have been used as perfumes, cosmetics, food additives and medicines (Muchtaridi, 1991).

Carrageenans, a family of linear sulfated polysaccharides, are found and extracted from the cell wall of certain species of red seaweeds (Rhodophyta). These natural polymers can form the more reversible gels or viscous solutions when added in small concentration to salt solutions. Therefore, they are commonly used as texturing, thickening, suspending, or stabilizing agents in various industrial applications ranging 
from food products, pharmaceutics, and cosmetics to experimental medicine (Zainab et al., 2019).

Soap is produced through a saponification reaction involving alkalis and oils. Soap is a mixture of sodium and fatty acids used as a body cleanser in solid or foam form and with or without other additives and does not cause skin irritation. Currently, soap is not only used as a cleanser to maintain healthy skin. Some soaps also function as softening soaps and whitening soaps depending on the additives added to the bath soap. Bath soap is a product derived from oil. The oil used is palm oil. Palm oil is mainly known as a raw material for oil and food fat used to produce cooking oil, shortening and margarine. Palm oil contains saturated fatty acids and unsaturated fatty acids whose molecular bonds are easily separated by alkalis. The alkaline used is $\mathrm{NaOH}$ because this base will produce solid soap. Solid soap uses sodium hydroxide $(\mathrm{NaOH})$, while liquid soap uses potassium hydroxide $(\mathrm{KOH})$ as an alkaline. Ideally, solid bath soap has a hardness that will provide sufficient lather (i.e., its behaviour as a foaming agent) to increase the cleaning ability of the soap (Natalia et al., 2018)

Residents of RT 02 / RW 03 Rungkut Barata, Surabaya City, are currently refining citronella oil, where the production is only in citronella oil with simple packaging. To increase the added value of citronella oil refining, it is necessary to diversify the processed product by combining seaweed and citronella oil as a raw material for making soap.

\section{Methods}

The implementation of community service activities was attended by residents of RT 02 / RW 03 Rungkut Barata Surabaya. Community service activities are carried out by providing counselling to 20participants. This community service activity includes product diversification of citronella oil refined products combined with carrageenan as raw material for making aromatherapy soaps. Before the extension activities were carried out, the media had to prepare first to do the counselling. This activity would take place at the sub-district office by providing an LCD projector. Before presenting material and product manufacturing practices, the participants will be given a questionnaire to find out about the identity, education level, age and knowledge of participants regarding citronella and seaweed products.

Furthermore, the related resource person explained the making of aromatherapy soap with a combination raw material of citronella oil and seaweed and the counselling of financial analysis, packaging, and marketing. The training participants will be given time to practice in groups so that it is hoped that the participants will be able to make the processed products themselves after the extension and training for community service ends. In addition, it is essential to know the participants' understanding of the packaging and promotion media for the sustainability of the combination of citronella oil and seaweed. Monitoring and evaluation will be carried out after the counselling and training process to increase participants' understanding of making products and their implementation so that they can be sold to the public

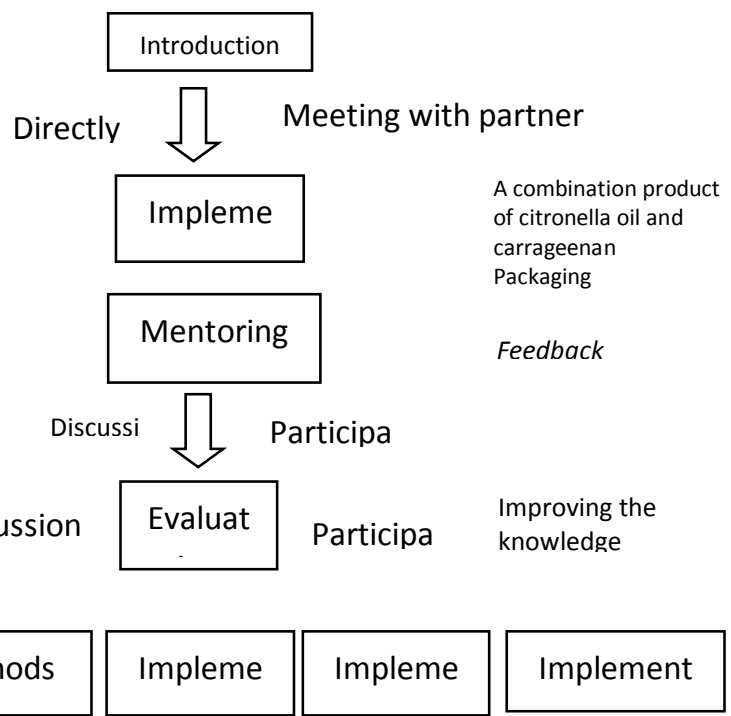




\section{Result and Discussion}

This community service activity has been carried out in the RT 02 / RW 02 Rungkut Barata,Surabaya. The potential of the residents of Rungkut Barata is to produce citronella oil from growing citronella by the residents themselves. However, no other processed product diversification has yet been raised. This community service activity introduces non-consumer processed products, namely a seaweed soap bar and citronella oil as a fragrance. The movement started by filling in attendance and distributing the book on non-consumption seaweed processing that the FPK Community Service team had compiled. Furthermore, the activity was opened by remarks from Mr Arief as a senior at the Rungkut Barata, followed by remarks from Mrs Dwi as the head of Community Service activities. In his speech, Mr Arief thanked the FPK UNAIR, who shared their knowledge about processing seaweed for nonconsumption into soap bar by empowering the potential of citronella oil that residents of Rungkut Barata residents have produced. Like a welcome paddle, Mrs Dwi also expressed her gratitude to RT 02 / RW 03 Rungkut Barata residents, who were pleased to welcome the community service team and prepare for these activities starting from communication, coordination, and implementation.

The activity begins with holding a pretest at the beginning of the meeting to determine the participants' basic understanding of the soap making process. The number of respondents was 20participants. The pre-test results showed that only $3(15 \%)$ out of 20participants had ever made soap. In general, participants are enthusiastic about making soap (100\%). Still, they do not understand the lathering reaction theory, the principles of making soap, procedures, raw materials, additives, and equipment that must be used to make soap.

The presentation started with the introduction of seaweed material and how to make a soap bar. Making their soap is easy and fun and has several benefits, including increasing creativity; homemade soap is safer because it does not contain sodium lauryl sulfate compounds, which can irritate the skin and can become a superior product for the people of Rungkut Barata in the future. The next step is making a soap bar by mixing the atrium hydroxide $(\mathrm{NaOH})$ solution with oil. Through a chemical reaction, $\mathrm{NaOH}$ converts oil/fat into soap. This process is called saponification. There are two ways to make soap, namely the cold process and the hot process. Soap with cold-process making opaque soap and hot-process method can produce the transparent soap. The equipment used to create soap includes digital scales, hand-blenders, double boiler pans, slow cookers, hot plates, various silicone soap moulds, plastic racks for drying soap, glass cups, silicone spatulas, wood stirrers, stainless steel filters and other supporting equipment.

The process of making soap begins with dissolving 53.4 grams of $\mathrm{NaOH}$ with 145.2 grams of distilled water. In dissolving $\mathrm{NaOH}$, make sure we pour $\mathrm{NaOH}$ into distilled water slowly, not the other way around, because dissolving $\mathrm{NaOH}$ will cause a reaction of heat and smoke. In the saponification process, excessive use of $\mathrm{NaOH}$ will cause the oil molecules to react so that the resulting soap product can cause the skin to become itchy and hot (Dunn, 2010).

Various methods can be used to prevent itching and heat due to excess $\mathrm{NaOH}$, including (1) The use of dilute hydrochloric acid in soap products to remove excess $\mathrm{NaOH}$ (Mabrouk, 2005); (2) Shaking the soap formula for at least 45 minutes to complete the saponification reaction (Hartini et al., 2017); and (3) Reducing the use of the amount of $\mathrm{NaOH}$ so that $\mathrm{NaOH}$ reacts appropriately with the oil used (Prabowo et al., 2016). After dissolving $\mathrm{NaOH}$, wait until the temperature drops to $32-35{ }^{\circ} \mathrm{C}$. The next step is to weigh 224 grams of olive oil and 167.5 grams of palm oil, but the two oils into the blender, and slowly put the cooled $\mathrm{NaOH}$ solution. Stirring is done until traces are formed (perfectly blended). Then add as much as 8.4 grams of seaweed and 1.2 grams of lemongrass oil to the blender. Next, turn on the blender for a while until the seaweed, fragrance, and trace have been thoroughly blended. Pour trace soap into the container/mould provided and store for 2-4 weeks before use. The formulation of making a soap bar with a cold process can be seen in Table 1. 


\begin{tabular}{|c|c|c|}
\hline Materials & $\begin{array}{l}\text { Amount } \\
(\%)\end{array}$ & $\begin{array}{l}\text { Amount } \\
\text { (gram) }\end{array}$ \\
\hline Palm oil & $27.9 \%$ & $\begin{array}{l}167.5 \\
\text { gram }\end{array}$ \\
\hline Olive oil & $37.3 \%$ & $\begin{array}{l}224 \\
\text { gram }\end{array}$ \\
\hline $\mathrm{NaOH}$ & $8.9 \%$ & $\begin{array}{l}53.4 \\
\text { gram }\end{array}$ \\
\hline Aquades & $24.2 \%$ & $\begin{array}{l}145.2 \\
\text { gram }\end{array}$ \\
\hline Carrageenan & $1.4 \%$ & $\begin{array}{l}8.4 \\
\text { gram }\end{array}$ \\
\hline $\begin{array}{l}\text { Citronella } \\
\text { oil }\end{array}$ & $0.2 \%$ & $\begin{array}{l}1.2 \\
\text { gram }\end{array}$ \\
\hline
\end{tabular}

The hot process soap-making process begins with dissolving 48 grams of $\mathrm{NaOH}$ with 130.2 grams of distilled water. In dissolving $\mathrm{NaOH}$, make sure we pour $\mathrm{NaOH}$ into distilled water slowly, not the other way around, because dissolving $\mathrm{NaOH}$ will cause a reaction of heat and smoke. After dissolving $\mathrm{NaOH}$, wait until the temperature drops to 32$35^{\circ} \mathrm{C}$. The next step is to weigh 339 grams of palm oil and 10.8 grams of stearic acid, then homogenize it into a container and heat it at $70{ }^{\circ} \mathrm{C}$ until the stearic acid melts and wait for the temperature to drop to $50{ }^{\circ} \mathrm{C}$. We then added with $\mathrm{NaOH}$ solution 64.2 grams of glycerin, 8.4 grams of seaweed and 1.2 grams of lemongrass oil as a fragrance. Homogenize/stir until trace is formed. Pour trace soap into the container/mould provided and store for 1-2 weeks before use. The formulation of making a soap bar with a cold process can be seen in Table 2 .

Table 2. formulation of making a soap bar

\begin{tabular}{lcl} 
& with a cold process \\
\hline Materials & $\begin{array}{l}\text { Amount } \\
(\%)\end{array}$ & $\begin{array}{l}\text { Amount } \\
\text { (gram) }\end{array}$ \\
\hline Stearic acid & $1.8 \%$ & $\begin{array}{l}10.8 \\
\text { gram }\end{array}$ \\
Palm oil & $56.5 \%$ & $\begin{array}{l}339 \\
\text { gram }\end{array}$
\end{tabular}

\begin{tabular}{lll}
$\mathrm{NaOH}$ & $8 \%$ & $\begin{array}{l}48 \\
\text { gram }\end{array}$ \\
Glycerin & $10.4 \%$ & $\begin{array}{l}62.4 \\
\text { gram }\end{array}$ \\
$\begin{array}{l}\text { Carrageenan } \\
\text { Citronella }\end{array}$ & $1.4 \%$ & $\begin{array}{l}8.4 \\
\text { gram }\end{array}$ \\
$\begin{array}{l}\text { Aquades } \\
\text { Aquam }\end{array}$ & $0.2 \%$ & 1.2 \\
& 21.69 & gram \\
& $\%$ & $\begin{array}{l}130.2 \\
\text { gram }\end{array}$ \\
\hline
\end{tabular}

The last training is a business analysis to provide an overview of the investment costs, the costs that must be incurred, and the amount of profit obtained from a production business. Economic analysis is essential because making souvenir soap is a businessoriented production process. After the soapmaking practice, they were followed by a discussion session. During the session, the community was enthusiastic and hoped that a return visit could be made to Rungkut Barata next year by processing seaweed into food products.

At the end of the series of activities, an evaluation was carried out in the form of a post-test to determine the increase in participant knowledge. The post-test was followed by respondents totalling 20 . The post-test results showed an increase in participants' understanding of the reaction theory of lathering and the principles of soap making.

\section{Conclusion}

The community service that has been carried out to residents in Rungkut Barata, Surabaya, East Java Province has received high enthusiasm, which is shown by increased confidence and motivation to participate in workshop and training activities. The participants synergize with the Faculty of Fisheries and Marine community service team, Universitas Airlangga, in innovating citronella oil to be aromatic soap, developing 
the partner's creativity, and improving welfare.

\section{References}

Faidliyah. 2017. Pembuatan Lilin Aroma Terapi Berbasis Bahan Alami. Jurnal Prodi Teknik Kimia Intitut Teknologi Malang.

Hartini, S., Soetjipto, H., Ryanto, C. A., Cahyanti, M. N., \& Hastuti, D. K. A. K. 2017. Pemberdayaan Anggota PKK di Desa Lembu dalam Membuat Kosmetik. Agrokreatif Jurnal Ilmiah Pengabdian Kepada Masyarakat, 2(2), 81-86

Muchtaridi. 1991. Penelitian Pengembangan Minyak Atsiri Sebagai Aromaterapi dan Potensinya Sebagai Produk Sediaan Farmasi. Jurnal Teknik Industri Pertanian 17(3):80-88.

Mabrouk, S. T. 2005. Making Usable, Quality Opaque or Transparent Soap. Journal of Chemical Education, 82(10), 1534.

Natalia Prieto Vidal, Oludoyin Adeseun Adigun, Thu Huong Pham, Abira Mumtaz, Charles Manful, Grace

Callahan, Peter Stewart, Dwayne Keough and Raymond Horatio Thomas. 2018. The Effects of Cold Saponification on the Unsaponified Fatty Acid Composition and Sensory Perception of Commercial Natural Herbal Soaps. Molecules 23: 1-20

Prabowo, S. A., Ardhi, M. W., \& Sasono, M. 2016. Pemberdayaan Masyarakat Desa Mojoporno Melalui Pelatihan Pembuatan Sabun dari Minyak Jelantah. Jurnal Terapan Abdimas, 1(1), 26-28.

Zainab Mohammed Al-Nahdi, Ahmed AlAlawi, and Insaaf Al-Marhobi. 2019. The Effect of Extraction Conditions on Chemical and Thermal Characteristics of Kappa-Carrageenan Extracted from Hypnea bryoides. Journal of Marine Biology. 1-10 